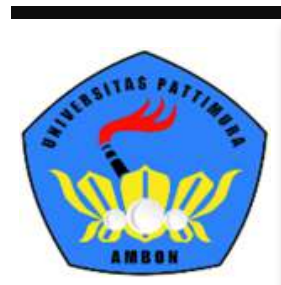

ISSN 2808-2265

Language Studies Centre

Pattimura Excellence Journal of Language and Culture

Journal Home page: https://ojs3.unpatti.ac.id/index.php/peilac

Journal Email: pejlac.unpatti@gmail.com

\title{
THE STUDENTS PERCEPTION OF LANGUAGE POLITENESS - BASED TEACHING MATERIALS IN SPEAKING SKILLS AT GERMAN LANGUAGE DEPARTMENT PATTIMURA UNIVERSITY AMBON
}

\author{
Juliaans Marantika, Carolina Lestuny, Eldaa C. Wenno \\ Germany Education Study Program, Pattimura University, Jl. Ir. M. Putuhena, Ambon
}

Article Informatioan :

*Corresponding author julians.marantika@yah oo.com

Received March, 9 2021; Revised April 11, 2021; Accepted May 18, 2021; Publication June 1, 2021

\begin{abstract}
This research aimed to obtain information about students' perceptions of politeness-based speaking skills teaching materials. The developed teaching materials were tried out in German Language Department, Pattimura University. The data was collected using a questionnaire technique to explore 18 students' perspectives on teaching materials, while data analysis related to student perceptions was carried out using descriptive analytic methods. The results showed that the theme chosen is a daily theme according to the daily communication needs of the beginner students, such as apologizing, asking, giving feedback or answering questions, giving suggestions, expressing opinions, etc. The teaching materials developed are also in accordance with the age level and students' language skills. Most of the students with language teaching materials that focus on (speaking skills) help them understand German language material easily. The form of training carried out by contrasting polite and unpolished utterances greatly helps students to distinguish appropriate speech according to politeness and will be able to use these speeches in daily communication. In addition, the teaching materials displayed are quite interesting because the form of practice used is quite good and interesting so that they can practice speaking and expressing opinions using polite language.
\end{abstract}

Keywords : Language Politeness, Teaching Materials, Speaking Skills

\section{INTRODUCTION}

Politeness is an aspect that contributes to acceptance in verbal communication. In oral communication, misunderstandings often arise due to neglect of politeness aspects. This misunderstanding is caused not only by the use of inappropriate language but also in the right context of communication. As a result, the good intentions were not appropriately delivered but instead created problems. In this case, the speaker's understanding of the situation and context of communication is needed. As cited in Pieklarz-thien (2012), there has been a growing interest in linguists researching politeness over the years (Ehrhardt, Neuland, Yamashita, 2011; Bonacchi, 2011; Engel, Tomiczek, 2010; Kimmich, Matzat, 2008). These studies provide many of the impulses and suggestions for the didactic consideration and application of foreign languages stem from recent politeness research.

There are several elements that determine the acceptability of a speech, namely who is talking to whom (participants), about what (topic), which situation (setting), which destination, route (written, spoken, telegraphic), and type of language. Both the recipient and the sender of the message must understand the ethics or norms in a society (Hymes, 1972). Since politeness is so important to the building and maintenance of social relationships, politeness in communication goes to the heart of social life and interactions; indeed it may be a prerequisite for human cooperation in general (Brown, 2015). 
The phenomenon of politeness has therefore attracted the interest of theorists in various social sciences. Yule (1996) (as cited in Mansoor, 2018) stated that the language used cannot be interpreted without referring to several aspects related to society. Most of the communication content can be identified through our social relationships because language is inherently related to our social interactions. This relation is important for maintaining a relationship with the interlocutor and ensuring that the communication developed is well received. Speaking skills are very necessary and must be used in daily life. The importance of speaking skills impacts on social relations. In regulating a language in speaking, misunderstandings can occur for listeners and make problems in communicating.

The emphasis on understanding with the interlocutor shows that communication partners always provide clues about how they feel about each other. That means communication partners also always provide information about how they relate to each other, how they respond positively to an interlocutor's statement, what positive responses are given to each other, and what rewards they claim themselves. What ritual patterns are used to open and close conversations that can shape the nature of their relationship with each other. Myers (1988) (as cited in Lüger, 1993) explained that the way couples express mutual respect can be less polite, depending on the strategies. The strategy in question is important for mutual protection between the speaker and the partner. This is because politeness of language shows awareness of the dignity of others in communicating, not only in speaking but also in writing. This definition explains the importance of maintaining social distance between the speaker and the interlocutor in communicating. That is, mastery of language structures and aspects of behavior can express mutual respect between speakers and interlocutors. In oral interactions, communication partners need to pay attention to language ethics.

Language ethics is also closely related to the selection of language codes, social norms, and cultural systems that apply in a society (Chaer, 2010; Sibarani, 2004). Hence, language ethics govern; (a) what we will say at certain times and circumstances to the interlocutors according to social and cultural status in society; (b) what kind of language makes the most sense to use in certain sociolinguistics and cultures; (c) when and how we use our turn to speak, and interrupt the conversation of others; (d) when we have to be quiet; (e) what are the quality of our voice and our physical attitude in speaking. Polite language is one of the norms that must be maintained in communicating. Politeness in a language is reflected in how to communicate orally or in language procedures. Yule (1996) stated that "... it is possible to treat modesty as a fixed concept, as in the idea of 'polite social behavior,' or etiquette, in a culture. In other words, in communication, politeness must be used as ethics, which uses language as a medium, to regulate the way of speaking.

Studies conducted related to foreign language teaching illustrate that oral communication skills are a fundamental element that can be a challenge for students. The choice of words and sentences that fit the context are some of the factors that complicate verbal communication. Níkleva (2011) or Núñez \& Hernández (2011) (as cited in Ramos-González \& Rico-Martín, 2015) considered politeness as a behavior that is acquired in the process of socialization and therefore needs to be included in the teaching process in English classrooms, as an important part of oral interaction and communicative competence. Lack of knowledge of the rules of courtesy can lead to complicated situations in conversation.

The developed communication pattern must be more directed at self-control and self-development that is balanced between knowledge, skills, and attitudes as intellectual candidates and educators. In this context, the use of language properly and correctly is an important part of identifying the image of educators and prospective professional educators. Thus, learning language skills, apart from focusing on language acquisition, also needs to teach language culture. Most of German language textbooks still ignore the practice of communication manners (Hüllen, 1981). Learning is more aimed at educating students to speak German in the context of everyday communication. Teaching materials related to politeness must be an important part of teaching. Meanwhile, in the didactic understanding of foreign language, politeness is mainly interpreted as competence to act in intercultural communication situations (Neuland, 2009). 
Hullen's opinion is strongly supported by the reality in most German language study programs in Indonesia, especially at Pattimura University. The teaching materials used have not even explicitly discussed politeness. Most of the learning process still focuses on using the language, grammar and vocabulary needed to strengthen the four basic language skills, namely listening, speaking, reading, and writing. In teaching modern foreign languages, learners must be ready to open, connect, and complete oral statements adequately. They need skills to behave in certain situations consistent with circumstances (i.e., with the proper knowledge, situation, and partner). It means that the learning process is expected to provide students with opportunities to gain knowledge of politeness in language, and the teaching materials used have accommodated polite ways of communicating (Marantika et al., 2020). This is important to pay attention to, considering that many German lessons only focus on mastering language skills. In the first stage of this research, politeness-based speaking skills have been developed to accommodate students' need for politeness in communicating, especially in speaking. This preliminary information has been used as the main material for the preparation and supplement of speaking skills, containing 14 main languages put forward by students, namely: (1) greeting, (2) asking for help, (3) asking and answering questions, (4) saying thank you, (5) borrowing something, (6) asking someone, (7) small speaking, (8) answering questions, (9) giving comments, (10) rejecting requests, (11) asking for something, (12) giving advice, (13) conveying information, (14) giving opinions. The teaching of politeness aspects takes place mainly in the lower levels of language proficiency (levels A1-B1), and it is mostly an implicit rather than explicit presentation of selected routinized politeness forms such as forms of address, forms of greeting and farewell, forms of thank you/please/excuse me, as well as elementary syntactic and lexical categories such as mode and modal verbs, particles, sentence adverbs, conditionals, negation, passivation, vagueness expressions, etc. (Pieklarz, 2011). The goal pursued in the textbook dialogues (conversations at the doctor's office, at the counter, explaining directions to someone unfamiliar with the place, etc.) is information transfer competence rather than conversational competence (Pieklarzthien, 2012).

Thus, the problems that wants to be solved through this research is how the opinion of the expert and the students' opinion about the teaching materials developed. Some questions that are used as basis in expressing their opinion are: (1) Have the teaching materials developed met the requirements as language politeness teaching materials? (2) Do the language learning that focuses on (speaking skills) helps them to understand the German language material, (3) Do the learning process which facilitated by lecturers in class helps them to understand the subject matter easily, (4) Do the students able to distinguish the appropriate utterances according to politeness and will be able to use these utterances in terms of communication, (5) Do the teaching materials that are displayed make them better to understand the material being studied, (6) Do the teaching materials used are very useful, (7) Do the teaching materials are quite interesting, even though there are vocabularies that are difficult to understand, and (8) Do this type of exercise is quite good and interesting because it can train them in speaking and expressing opinions.

\section{METHODOLOGY}

\subsection{Instruments}

To collect data related to expert assessments to determine the feasibility of the developed teaching materials using content validation tests. Meanwhile, to determine students' response this research used questionnaire from 20 questions given with two aspects are: (1) language politeness which is divided into three parts, namely attitudes, interests and material linkages. (2) language learning which also consist of three parts, namely attitudes, interests and material linkages.

\subsection{Data collection}

The suitability of the theme with the learning objectives, the appropriateness of the theme with student needs, student understanding of the theme, and teaching materials to students' language skills 
were assessed in this study. The trial involved 18 students. A theme is determined and taught to a group of third-semester students in the A2 Aufbaustufe course. After the learning process, questionnaires were distributed to students to determine their opinions about the teaching materials used. Some of the aspects that were asked were students' perceptions of learning speaking skills based on politeness material.

\subsection{Data analysis}

This research is descriptive-analytical that serves to describe or give an overview of the object under study through data or samples that have been collected as they are without doing analysis and making conclusions that apply to the public. The research was carried out in the German Language Department, Faculty of Teacher Training and Education, Pattimura University. The implementation phase was carried out through Expert Judgment and tray out. Expert Judgment or Expert opinion was obtained through three lecturers in the German Language Education department who are experienced in developing teaching materials and learning German language and culture skills.

\section{FINDING AND DISCUSSION}

The analysis of the expert assessment illustrated that, in general, the teaching materials developed had met the requirements as teaching materials. The teaching materials were already developed, easy to understand because they suited the students' level of understanding. The themes chosen were everyday themes adapted to the needs of students' daily communication, such as apologizing, asking, responding to questions, giving suggestions, expressing opinions, and so forth. The teaching materials developed were also in accordance with the students' age level and language skills, namely A2.

The result can be seen in the following diagram.

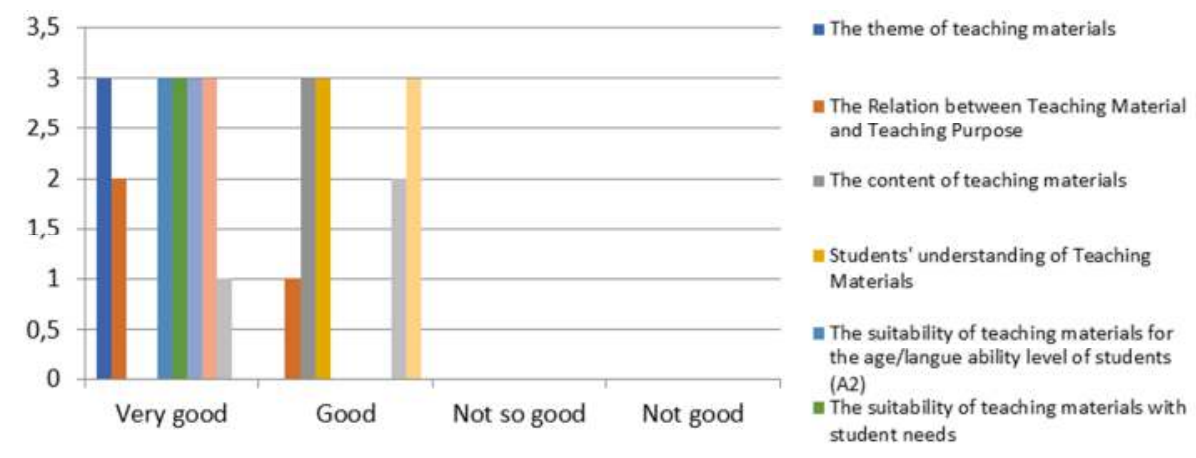

Figure 1. Expert Validation Results

Based on the results of the assessment by the validator, it can be concluded that the teaching materials have met to the content and construct requirements. However, there were some suggestions related to general matters such as the appearance of the cover of teaching materials that must be made more attractive with colors and pictures, a table of contents and pages to the teaching material, and a glossary to help the student understands.

As is known, several aspects that were also explored from students related to the implementation of politeness-based speaking skills, included: (1) Do the language learning that focuses on (speaking skills) helps them to understand the German language material, (2) Do the learning German facilitated by lecturers in class helps them to understand the subject matter easily, (3) Do the students able to distinguish the appropriate utterances according to politeness and will be able to use these utterances in terms of communication, (4) Do the teaching materials that are displayed make them better to understand the material being studied, (5) Do the teaching materials used are very useful, (6) Do the teaching 
materials are quite interesting, even though there are vocabularies that are difficult to understand, and (7) Do this type of exercise is quite good and interesting because it can train them in speaking and expressing opinions.

As written for research purposes namely to obtain information about students' perceptions of politeness-based speaking skills teaching materials, as illustrated in Figure 2, the analysis results indicated that, in general, speaking skills learning by including the element of politeness in the teaching material is considered good. Students understood the forms of speech that should be used to ask the interlocutor to do something or respond to the conversation without neglecting politeness. The result can be seen in figure 2 below.

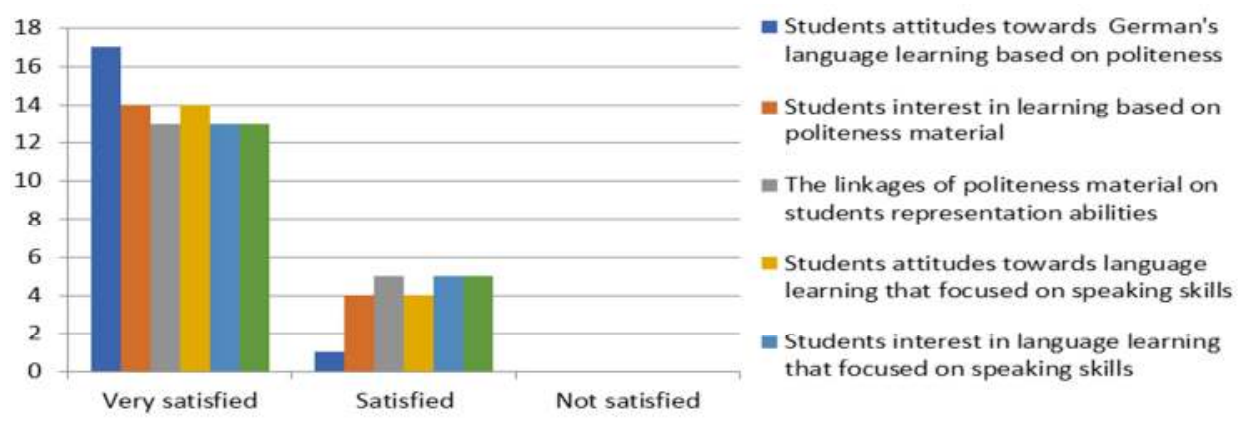

Figure 2. The Resuts of The Student Perception

In general, the results of the analysis show that students can understand the forms of speech that should be used to ask a speech partner to, for example, do something or respond to a conversation without neglecting politeness. This is very possible because the form of training given is quite interesting and motivates them. The increase in students 'understanding of the use of politeness-based speaking skills teaching materials indicates that politeness in speaking needs to be taught because it will have a positive impact on students' speaking skills. This is in line with another research that found that the level of language politeness in speaking by students who learn with the class meeting model using polite language textbooks is very high and is in the very polite category (Astuti, 2012). In the developed learning material, students are not only asked to understand utterances to ask or convey something properly and correctly, but also how the meaning is conveyed politely. This can be seen in following exercises:

In example (1) students are asked to choose which speech is polite and which is not polite/rude: Ms. Lenzi speaks to the German colleague about the video tapes

1. Which statement sounds polite (+), which sounds rude (-)?

a. Why did you just take the tapes with you? It is customary for us in such situations to ask whether something can be kept or whether something must be given back

b. Please excuse me! I think there is misunderstood. I think I only lent you my own tape and I would like it back because they are special video tape from abroad. I'm embarrassed, but ...

c. I want my video tape back. I expect you to return it to me at once. You can't just leave with my tape. In my opinion that is unbelievable!

d. Ifeel uncomfortable talking about it. You asked me the other day to get you video tapes. My apologies, but I didn't tell you I gave you my own tape. I am sure you will understand that I would like it back. You know, my father brought them for me from abroad.

As in the following example (2), the exercises can be designed in a playful manner and not only have to be based on the usual course of action; You can first present the first part (a) of the role play in class and then have the students follow up with further requests. 
Exercises on the use of the imperative

The boss, the first, the second, the third, the fourth

a. The boss to the first: May I ask you to bring a chair.

b. The first to the second: bring the boss a chair, please!

c. The second to the third: Please a chair for the boss!

d. Third to fourth: bring the boss a chair, go!

e. The fourth: Immediately

The fourth always does what he can do.

In example (3) Students were asked to give their opinion about their friends new haircut. They actually didn't really like their friend's haircut but they tried to cover it up and chose indirect speech (try to be polite). What should be the answer?
a. Fine (and change the topic)
b. Is this perhaps the new trend? Honestly, it's not your style
c. You used to look better.
d. You know what, it wasn't the best idea.
e. Unbelievable, it couldn't be worse
f. Look at you
g. What have they done to you?

By giving students the opportunity to choose the form of speech that is polite and what is not, as in exercise (1) above, students have the opportunity to clearly see which utterance is most appropriate for requesting a loan video. record or comment. to a friend's haircut, without neglecting modesty. In exercise (1) it is possible that the requested video recording will be returned because it is politely requested, the borrower does not lose face. The same applies to exercise (3), using the indirect form, the friend does not lose face or be ashamed, even though her friend's haircut is not liked. This is consistent with the concept of politeness put forward by Brown and Levinson's theory, in contrast, the correlation between indirect and modesty stems largely from the view of modesty as a deviation from Grice's (1975) Principles of Cooperation. They distinguished between three main levels of overt in engaging in face-threatening actions: The un-recorded strategy explicitly ignored Grice's conversational principles and focused on facial improvement, while the on-tape strategy combined with the corrective action had the advantage of being clear and polite. equivalent time (Brown and Levinson 1987).

Whereas in practice (2) politeness is very much determined by the social level of the speakers. The higher the social level of a person, the language used is more polite, conversely, the lower the speech used, the less polite or rude. By learning directly through exercises as exemplified, students can more quickly recognize forms of politeness speech that must be mastered.

\section{CONCLUSION AND SUGESTION}

Based on the research results that have been explained, the researchers concluded several things, as follows:

a. Language politeness is an important aspect of oral communication because it can avoid misunderstanding due to cultural differences.

b. Learning foreign languages, especially German, should not only focus on mastering grammar and vocabulary but also on politeness. In that way, students have the opportunity to practice using communicative utterances that contain elements of politeness. 
c. The teaching materials developed can be used to answer the gaps in teaching materials skills based on politeness.

d. The themes developed are following the goals and needs of students' daily communication, containing the knowledge of polite culture in German, easy to understand, and attract students' interest.

Based on these conclusions, it can be suggested that that lecture should use the language politeness-based teaching materials in the speaking class to increase students' language politeness in the class and the environment around them.

\section{REFERENCES}

Astuti, P. K. (2012). Perbedaan Tingkat Kesantunan Berbahasa Aspek Berbicara dan Menulis Hasil Belajar Menggunakan Buku Ajar Santun Berbahasa Indonesia dan Bahasa Indonesia (BSE) pada Siswa Kelas VII SMP dengan Model Pertemuan Kelas. Seloka: Jurnal Pendidikan Bahasa Dan Sastra Indonesia, 1(1), 70-78.

Brown, P. (2015). Politeness and Language. In International Encyclopedia of the Social \& Behavioral Sciences: Second Edition (pp. 326-330). Elsevier Inc. https://doi.org/10.1016/B978-0-08-097086$8.53072-4$

Brown P, Levinson CS. Politeness: Some Universals of Language Usage. Cambridge: Cambridge University Press; 1987

Chaer, A. (2010). Kesantunan Bahasa. Rineka Cipta.

Hüllen, W. (1981). Lehrbuchdialoge und Linguistische Gesprächanalyse. In H. Brückner (Ed.), Lehrer und Lernende im Deutschunterricht (pp. 266-269). Langenscheidt.

Hymes, D. (1972). On Communicative Competence In: J.B. Pride and J. Holmes. In Sociolinguistics. Selected Readings (pp. 269-293).

Lüger, H.-H. (1993). 6: Routinen und Rituale in der Alltagskommunikation. Langenscheidt.

Mansoor, I. K. (2018). Politeness: Linguistic study. International Journal of Research in Social Sciences and Humanities, 8(4), 167-179. https://www.researchgate.net/profile/ImanMansoor/publication/330741875_POLITENESS_LINGUISTIC_STUDY/links/5c521e69458515a4c 74c3c34/POLITENESS-LINGUISTIC-STUDY.p̄df

Marantika, J. E. R., Tomasouw, J., \& Siang, J. L. (2020). Politeness in German as a foreign language learning process in Pattimura University. Systematic Reviews in Pharmacy, 11(3), 661-666. https://doi.org/10.31838/srp.2020.3.89

Neuland, E. (2009). Kritisieren und Komplementieren: Ergebnisse kontrastiver Studien deutschitalienisch zum Umgang mit sprachlicher Höflichkeit. In C. Erhardt \& E. Neuland (Eds.), Sprachliche Höflichkeit in interkultureller Kommunikation und im DaF-Unterricht (pp. 153-170). Lang.

Pieklarz-thien, M. (2012). Sprachliche Höflichkeit und gesprochene Sprache in der philologischen Sprachausbildung: anwendungsorientierte Überlegunged. Acta Neophilologica, 14(2), 79-95.

Pieklarz, M. (2011). Sprachliche Höflichkeit und gesprochene Sprache in der philolo gischen Sprachausbildung - gesprächsanalytisch motivierte Überlegungen. In E. Neuland, C. Ehrhardt, \& H. Yamashita (Eds.), Sprachliche Höflichkeit zwischen Etikette und kommunikativer Kompetenz, Series: Sprache - Kommunikation - Kultur (pp. 303-324). Lang.

Ramos-González, N. M., \& Rico-Martín, A. M. (2015). The Teaching of Politeness in the Spanish-as-aforeign-language (SFL) Classroom. Procedia - Social and Behavioral Sciences, 178(November 2014), 196-200. https://doi.org/10.1016/j.sbspro.2015.03.180

Sibarani, R. (2004). Kesantunan bahasa. Antropolinguistik, October, 6-8.

Yule, G. (1996). Pragmatics. Oxford University Press. 